\title{
SEMI-AUTOMATIC DRAIN FOR SEWAGE WATER TREATMENT OF FLOATING MATERIALS
}

\author{
Ganesh U L ${ }^{1}$, Vinod V Rampur ${ }^{2}$ \\ ${ }^{1}$ Assistant Professor, Mechanical Department, PESITM, Shimoga, Karnataka, India
}

\begin{abstract}
In this research paper the proposed concept is to replace the manual work in drainage cleaning by mechanical drain cleaner. Now-a-days even though mechanical drainage plays a vital role in all industrial applications in the proper disposal of sewages from industries and commercials are still a challenging task. Drainage pipes are using for the disposal and unfortunately sometimes there may be loss of human life while cleaning the blockages in the drainage system. To overcome this problem and to save human life we implement a design "mechanical semi-automatic drainage water cleaner" and we designed our project to use this in efficient way to control the disposal of wastages and with regular filtration of wastages. The Drainage system cleaner is a machine which helps to protect the environment from different kinds of environmental hazards through the promotion waste management by the removal of garbage from the drainage system. These wastes when not removed end up settling in residential places where these wastes are burnt thereby causing climate change otherwise these wastes block the drainage systems thereby causing flooding.
\end{abstract}

Keywords: Mechanical drainer system.

\section{INTRODUCTION}

Water is a basic necessity of humans and all living beings. There is a plenty of water on earth but that is not suitable for human use. Clean water is more important if used for some purpose. The impurities present in water can cause hazardous and disease. As long as the draining system is considered the function of the main drainage system is to collect, transport and dispose of the water through an outfall or outlet. Impurities in drainage water can be only like empty bottles, polythene bags, papers......etc. These impurities present in drainage water can cause blockage or the drainage system. The drainage system can be cleaned time to time manually or such a system can be designed that will automatically throw out wastages and will keep the water clean. This project is designed to keep clean the drainage system and helps the smooth working of the system. This project automatically cleans the water in the drainage system each time any wastage appears and this form an efficient and easy way of cleaning the drainage system and preventing the blockage. It also reduces labour and improves the quality of water that is cleaned. If the garbage are allowed to flow the will end up flowing down to recreational beaches used for tourism purposes making a scene not pleasurable to the eyes else these garbage flow to residential sites where they are burnt in a way of getting rid of them, thereby causing climate change. The drainage systems are cleaned when there is no water in them i.e. when it is not raining, but when it is raining the drainage systems cannot be cleaned because of the harsh conditions of the rain which no one would volunteer to endure to ensure garbage does not enter into the drainage systems.

\section{LITERATURE SURVEY}

\begin{tabular}{|c|c|c|}
\hline $\begin{array}{l}\text { System and } \\
\text { Scientists }\end{array}$ & Outcome & Drawbacks \\
\hline $\begin{array}{l}\text { Program logic } \\
\text { control } \\
\text { (JIANG Jing } \\
\text { and ZHANG } \\
\text { Xuesong(2014) }\end{array}$ & $\begin{array}{l}\text { Automatic control } \\
\text { of sewage treatment }\end{array}$ & $\begin{array}{l}\text { It is not depend } \\
\text { on deposited } \\
\text { sludge of the } \\
\text { drainage system }\end{array}$ \\
\hline $\begin{array}{l}\text { Akio Goto and } \\
\text { Kazuyuki } \\
\text { Yamasaki(2014 } \\
\text { ) }\end{array}$ & $\begin{array}{l}\text { By using of } \\
\text { microorganisms } \\
\text { produced the toxic } \\
\text { gases and not toxic } \\
\text { gases }\end{array}$ & $\begin{array}{l}\text { Gases effect on } \\
\text { human beings }\end{array}$ \\
\hline $\begin{array}{l}\text { Drainage pump } \\
\text { monitoring and } \\
\text { control system } \\
\text { (WU } \\
\text { JingCHEN, } \\
\text { Guo jie 2014) }\end{array}$ & $\begin{array}{l}\text { Collection of } \\
\text { operation } \\
\text { parameters of } \\
\text { underground } \\
\text { drainage pump and } \\
\text { automatic control } \\
\text { startup and } \\
\text { shutdown of } \\
\text { drainage pump }\end{array}$ & $\begin{array}{l}\text { It does not gives } \\
\text { the problem } \\
\text { solving } \\
\text { procedure }\end{array}$ \\
\hline $\begin{array}{l}\text { Wireless real } \\
\text { time system } \\
\text { Yin Haling Xu } \\
\text { Zuxin(2014) }\end{array}$ & $\begin{array}{l}\text { In this defined only } \\
\text { for the monitoring } \\
\text { of the drainage } \\
\text { system }\end{array}$ & $\begin{array}{l}\text { It does not define } \\
\text { how to control } \\
\text { the drainage } \\
\text { water }\end{array}$ \\
\hline $\begin{array}{l}\text { Wireless real } \\
\text { time } \\
\text { observation } \\
\text { system } \\
\text { Wang Juan } \\
(2014)\end{array}$ & $\begin{array}{l}\text { It shows how to } \\
\text { control storm } \\
\text { drainage so as to } \\
\text { reduce dry weather } \\
\text { pump discharging }\end{array}$ & - \\
\hline
\end{tabular}




\section{OBJECTIVES}

The major objectives of the proposed work are, Design of mechanical drainer, taking into account the various factors that might affect the functionality of the equipment. Fabrication of the model and Assembling of the model carriedout, then process are studied and optimized for effective semi-automatic drainer for sewage water treatment for floating materials.

\section{METHODOLOGY}

The device is place across a drain so that only water flows through the lower basement. Floating waste like bottles, plastic cans, covers.....etc. is lifted by lifters which are connected to the chain. The chain revolves with the sprocket wheel which is driven by the motor. The energy provided to the motor is electrical energy. When motor runs the chain starts to circulate making the lifter to lift up. The wastage material are lifted by lifter teeth and stored in storage or collecting bin. Once the collecting bin is full, the waste materials are removed from the bin.

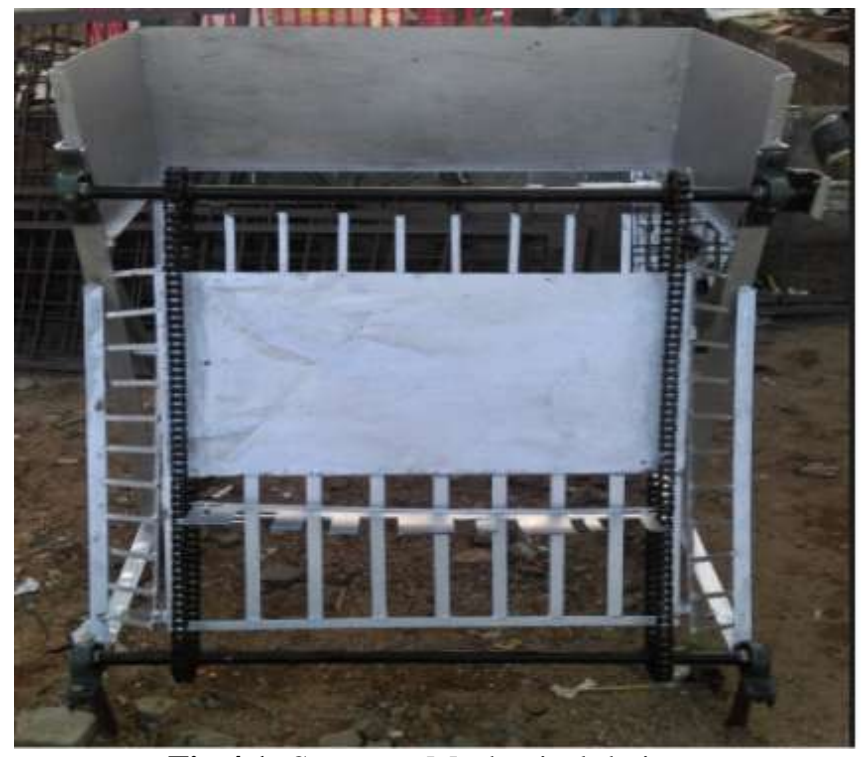

Fig 4.1: System - Mechanical drainer

\subsection{Bill of Materials}

Table 4.1: Bill of material List

\begin{tabular}{|l|l|l|}
\hline PARTS & MATERIALS & QUANTITY \\
\hline Sprockets & Stainless steel & 4 \\
\hline Motor & Cast iron & 1 \\
\hline Shaft & Mild steel & 2 \\
\hline Sheet metal & G.I Sheet & 3 \\
\hline Chain & Stainless steel & 4 \\
\hline Iron bars & Cast iron & 9 \\
\hline $\begin{array}{l}\text { Fabrication of } \\
\text { lifter and box }\end{array}$ & $\begin{array}{l}\text { Mild steel and } \\
\text { G.I Sheet }\end{array}$ & 3 \\
\hline Paint work & Paint(silver) & 1 \\
\hline
\end{tabular}

\subsection{Design of Mechanical Drainer}

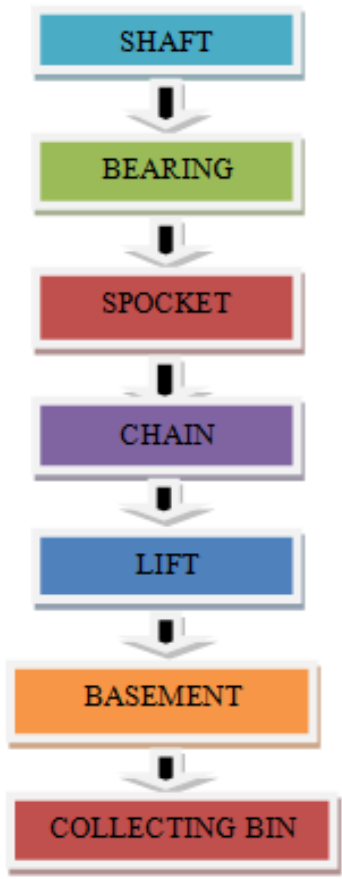

Fig 4.2: Flow chart for design calculation

\subsection{Design Inputs}

\subsubsection{Shaft}

Material used=Mild steel.

Length $=910 \mathrm{~mm}$

Inner Diameter $=21 \mathrm{~mm}$

Outer Diameter $=24 \mathrm{~mm}$

Length between shaft to shaft $=930 \mathrm{~mm}$

Power transmitted by the shaft $=108577.5105$ watt

\subsubsection{Maximum Bearing Load}

$$
\frac{L}{g}=\frac{248.256}{9.81}=25.3064 \mathrm{Kg}
$$

If the weight exceeds more than the calculated weight the load on the bearing will increase due to which there will be improper rotation of the chain occurs.

\subsubsection{Chain Drives}

$\mathrm{P}=11.372 \mathrm{~mm}$.

Chain length $=\mathrm{L}=\mathrm{p} L_{p}=2057.4 \mathrm{~mm}$

\subsubsection{Lifter}

Length $=610 \mathrm{~mm}$

Breadth $=120 \mathrm{~mm}$

Gap between each lifter $=700 \mathrm{~mm}$

\subsubsection{Collecting Bin}

Length $=920 \mathrm{~mm}$

Breadth $=610 \mathrm{~mm}$

Height $=340 \mathrm{~mm}$

Area of the collecting bin $=\frac{1}{2} \times \mathrm{L} \times \mathrm{B}=280600 \mathrm{~mm}$ 


\subsection{Fabrication of Model}

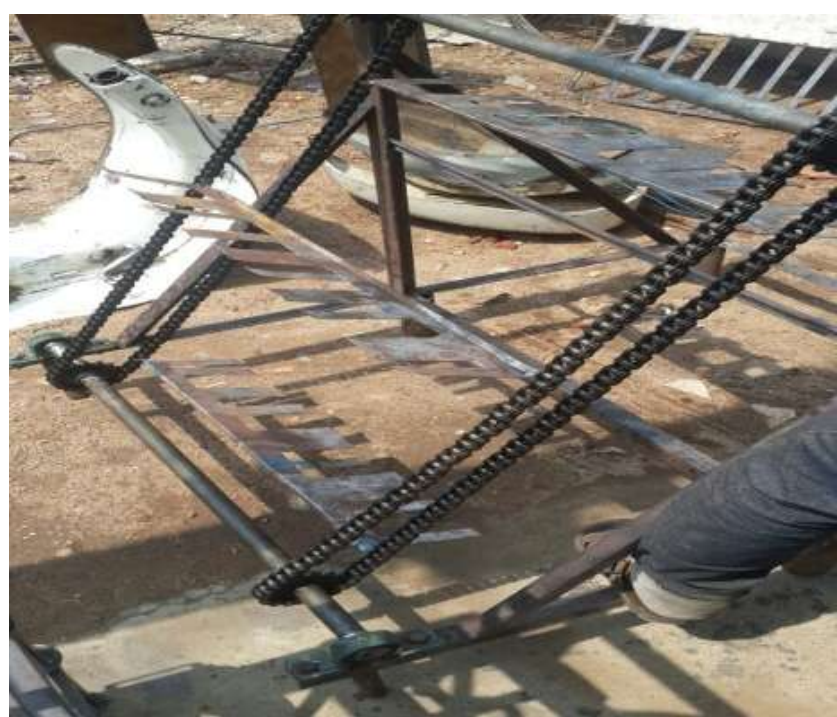

Fig 4.3: fabrication of the model

Basically during fabrication of the model the basement part is prepared by welding the metal bars by electric welding. Then the supporting rods are welded at an angle of 90 degree from the basement, the pillow block bearings are fixed to the supporting rod and the front part of the basement. Hollow cylindrical shafts are fixed to the bearings and also chain drive are also fixed to the shaft in order to fix the shafts the factor of safety of the chain is calculated. The lifters are fixed to the chain by gas welding at an equal distance from each.

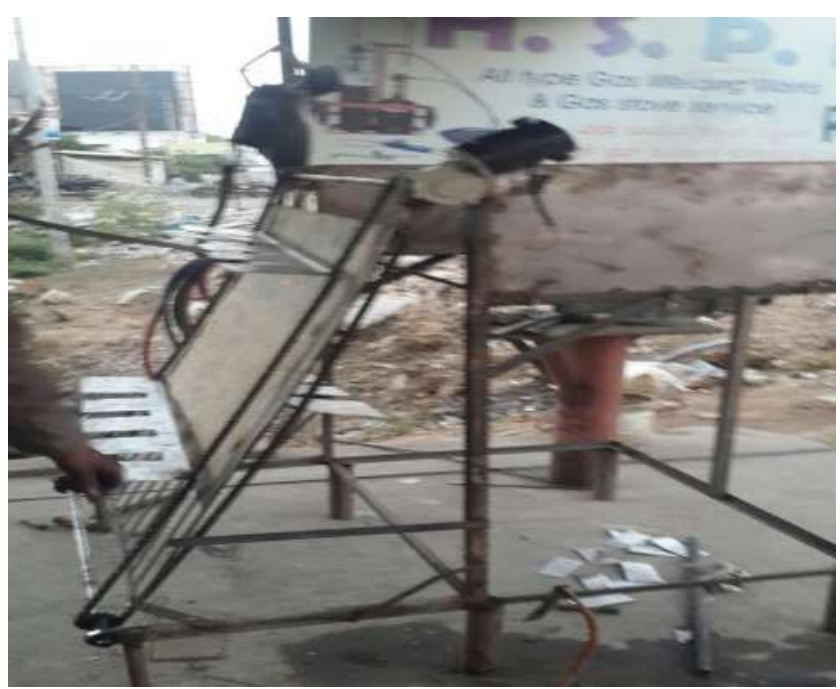

Fig 4.4: fabrication of the model

\section{RESULTS AND DISCUSSION}

While conducting the experiment the parameters considered are uniform flow rate of water, depth of the channel is 1 feet and height of the channel is 3feet, rate of disposal of waste is uniform, lifter speed and motor speed is constant.

a. Alarm will turn on when the collecting bin is filled.

b. Lifter speed is constant and it regularly lifts the waste.

c. Cost of the machine is economic and it requires only 12-24 volts of current.

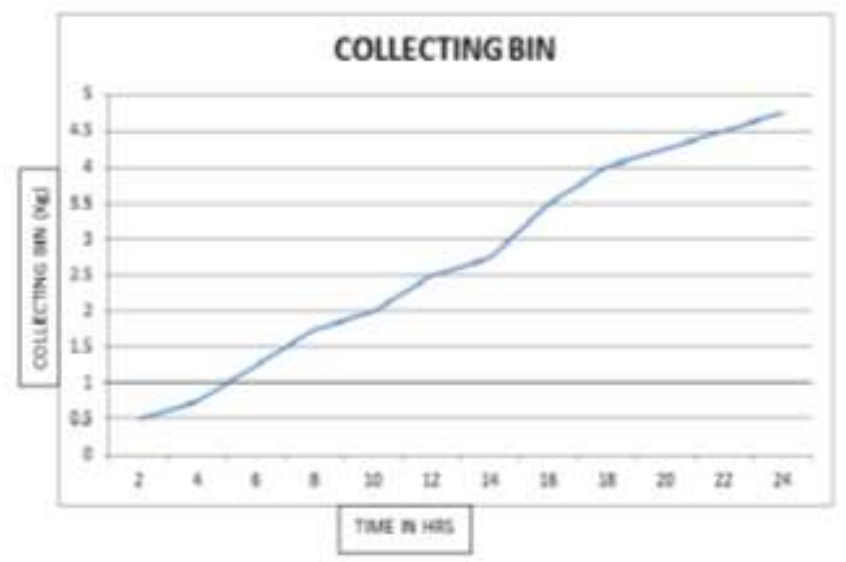

Fig 5.1: graph of time v/s collecting bin.

a. Time taken by each lifter to lift each object from bottom to top is 11.46 seconds.

b. Min time taken by collecting bin to fill completely is 1 day.

c. Quantity of waste collecting in the collecting bin is nearly 8-9 kilograms.

d. The below graph which is drawn time v/s collecting bin explains that how much waste is collected in the bin with respect to time.

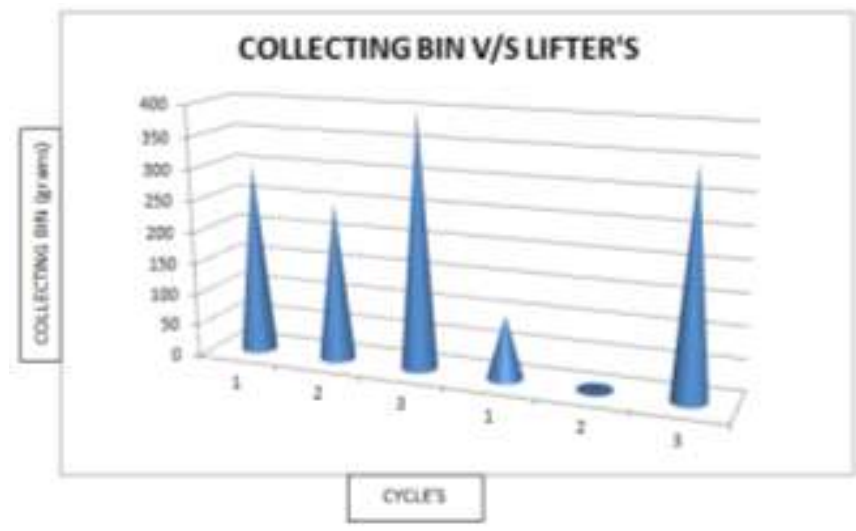

Fig 5.2: - graph of cycle v/s collecting bin

While considering the above graph collecting bin $\mathrm{v} / \mathrm{s}$ one complete cycle indicates that the rate of lifter lifting the waste is directly proposal to the storage of waste in the collecting bin.

\section{Advantages}

a. These cleaners are easy cheapest way to fix drainage problems. Easy to operate as no special skill is required.

b. Reduction of labour oriented method of cleaning, thus upgrading dignity of labour.

c. Light weight and easily portable. Requires nearly 12-24 volts of power.

d. Large amount of garbage will collect which can be remanufacturable.

\section{Disadvantages}

a. Small vibration will occur.

b. In order to avoid vibration the machine should be properly foundation with the floor. 


\section{Applications}

a. It is used almost in all types of drainage (Large, Small, and Medium).

b. Project to use this in efficient way to control the disposal of wastages and with regular filtration of wastages.

c. Cleaning and maintenance of sewer lines drains of mechanical drainer.

\section{CONCLUSION}

- In the treatment system of drainage Waste water control by the motor, roller chain and sprocket, lifter and the collecting bin to achieve semi-automatic control of sewage waste water treatment.

- Drainage from industries is treated through this project to meet the national emission standards, with stable operation, low cost and good effect.

- Drainage wastewater control is treated by this method to irrigate plants, clean toilets, etc.

- The cleaner functioned move effectively during the heavier rains which had more volume of running water with garbage and high velocity.

\section{ACKNOWLEDGEMENT}

The authors wish to thank the management of PES Institute of Technology and Management and Head of the department for providing the facilities to carry out this work. I also would like to express my deep sense of gratitude to my UG students, department of Mechanical Engineering, for their support during this project work.

\section{REFERENCES}

[1] International Refereed Journal of Engineering and Science (IRJES)ISSN (Online) 2319-183X, (Print) 2319-1821 Volume 3, Issue 3(March 2014), PP.54-60.

[2] International journal of innovative research in technology 2014 IJIRT Volume 1 Balachandra.G1, Karthikeyan.S2, Elangovan.K3, and Divya.N4. 1,2,3B.E/EEE Final year, Knowledge Institute of Technology, Salem, India4Assistant professor, Department of EEE, Knowledge Institute of Technology, Salem, India.

[3] Theory of machines -S S Rattan Department of Mechanical Engineering Regional Engineering College Kurukshetra (2004). Publication: Tata McGraw-Hill Publishing company Limited.

[4] Design of machine elements (DME-II) by K Raghavendra .first edition 2015.

[5] Design and Data hand book for Mechanical Engineers by $\mathrm{K}$ Mahadevan and $\mathrm{K}$ Balaveera reddy. Fourth edition 2013. 